\title{
A compound odontoma in the path of an erupting incisor
}

\author{
C R Gururaju, ${ }^{1}$ Vandana J Rathva, ${ }^{2}$ Chikkaiah Usha, ${ }^{3}$ K J Sundaresh ${ }^{4}$
}

${ }^{1}$ Department of Oral \& Maxillofacial Surgery, Sharavathi Dental College and Hospital, Shimoga, Karnataka, India

${ }^{2}$ Department of Periodontics, K.M. Shah Dental College and Hospital, Sumandeep

Vidyapeeth, Vadodara, Gujarat, India

${ }^{3}$ Department of Oral Medicine \& Radiology, Sharavathi Dental College and Hospital, Shimoga, Karnataka, India

${ }^{4}$ Department of Conservative and Endodontics, K.M Shah Dental College \& Hospital, Sumandeep Vidyapeeth, Vadodara, Gujarat, India

\section{Correspondence to}

Dr Vandana J Rathva, drvandana07@hotmail.com
To cite: Gururaju CR, Rathva VJ, Usha C, et al. BMJ Case Rep Published online: [please include Day Month Year] doi:10.1136/ bcr-2013-200825

\section{DESCRIPTION}

A 12-year-old girl presented with a missing upper front tooth. Extra oral examination was unremarkable. On intraoral examination, the right maxillary central incisor was missing (figure 1). Other quadrants had all permanent teeth from incisors to second molars. No abnormalities were detected on soft tissue examination. An intraoral periapical radiograph showed a radiopaque structure at the distoincisal aspect of impacted right maxillary central incisor resembling a mini-tooth like structure surrounded by a radiolucent halo (figure 2). A provisional diagnosis of compound odontoma was considered. On excisional biopsy, the gross specimen showed two calcified structure, one in the form of a mini tooth like structure and another spherical calcified mass. On histopathological examination, the $H \& E$ stained section of the specimen showed pulp space and dentine in normal relationship and the attached connective tissue consisted of collagen fibre bundles with interspersed fibroblasts and a slit-like vascular space suggestive of compound odontoma.

The missing maxillary central incisor is less commonly encountered in dental practice accounting for $0.06-0.2 \%{ }^{1}$ Since it is a highly demanding area from aesthetics, phonetics and functional point of view; it requires early detection with wellsynchronised and interdisciplinary approach to obtain an acceptable results. ${ }^{1}$ Supernumerary teeth and odontomas are the most common cause. About $56-60 \%$ of supernumerary teeth cause impaction of the permanent incisors due to a direct obstruction for the eruption. ${ }^{2}$

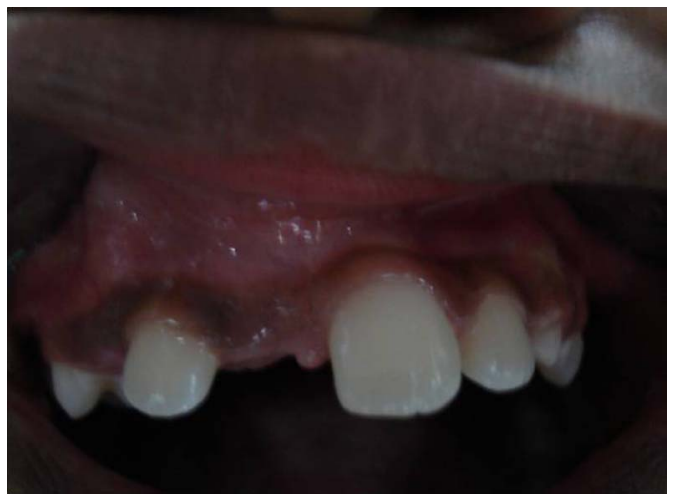

Figure 1 Intraoral view showing missing right maxillary central incisor.

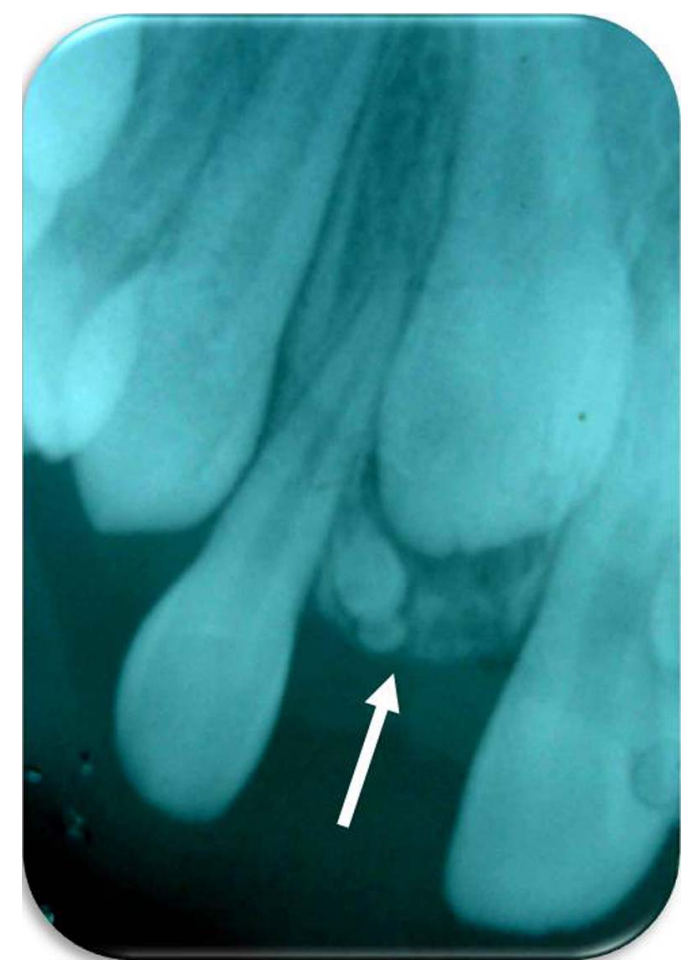

Figure 2 Radiograph showing embedded right maxillary central incisor whose eruption was blocked by a calcific mass.

\section{Learning points}

Proper evaluation of patients for any missing teeth in mixed dentition period.

- Compound odontoma is one common cause of missing incisors.

- It mandates early diagnosis and management of missing incisors as it have effect on self esteem and general social interaction.

Contributors All authors have made substantive contribution to this manuscript, and all have reviewed the final paper prior to its submission.

Competing interests None.

Patient consent Obtained.

Provenance and peer review Not commissioned; externally peer reviewed.

\section{REFERENCES}

1 Grover PS, Lorton L. The incidence of unerupted permanent teeth and related clinical cases. Oral Surg Oral Med Oral Pathol 1985;59:420-5.

2 Tanki JZ, Nagesh TA, Gupta A, et al. Impacted maxillary incisor: causes, diagnosis and management. IOSR J Dent Med Sci 2013;5:41-5. 
Copyright 2013 BMJ Publishing Group. All rights reserved. For permission to reuse any of this content visit http://group.bmj.com/group/rights-licensing/permissions.

BMJ Case Report Fellows may re-use this article for personal use and teaching without any further permission.

Become a Fellow of BMJ Case Reports today and you can:

- Submit as many cases as you like

- Enjoy fast sympathetic peer review and rapid publication of accepted articles

- Access all the published articles

- Re-use any of the published material for personal use and teaching without further permission

For information on Institutional Fellowships contact consortiasales@bmjgroup.com

Visit casereports.bmj.com for more articles like this and to become a Fellow 